\title{
DAMPAK PENUTUPAN LOKALISASI \\ TERHADAP MASYARAKAT SEKITAR KELURAHAN PUTAT JAYA KECAMATAN \\ SAWAHAN KOTA SURABAYA \\ (STUDI KASUS : LOKALISASI DOLLY SURABAYA)
}

\author{
Impact Of Closing Localization Towards The Citizen Arround Putat Jaya Village, Subdistrict Of \\ Sawahan Kota Surabaya \\ (Case Study: Surabaya Dolly Localization)
}

Mohammad Natsir 1

${ }^{1}$ Magister Ilmu Administrasi Universitas Kadiri

\begin{abstract}
Abstrak
Penutupan Lokalisasi Dolly oleh Pemerintah Kota Surabaya menjadi salah satu berita yang menggemparkan, karena lokalisasi ini merupakan lokalisasi yang terbesar di Asia Tenggara. Penelitian ini membahas tentang kebijakan pemerintah menutup Lokalisasi Dolly Surabaya dan dampak sosial ekonomi yang terjadi pasca penutupan. Metode yang digunakan dalam penelitian ini adalah deskriptif kualitatif. Sumber diperoleh melalui wawancara. Temuan riset menunjukkan bahwa dampak yang ditimbulkan akibat penutupan lokalisasi sangat dirasakan oleh pelaku usaha yang menggantungkan hidupnya di daerah sekitar lokalisasi. Pelaku usaha mengeluhkan tingkat pendapatan yang mulai menurun, hal itu dirasakan oleh warung makanan dan minuman, tukang parkir, buruh cuci, hingga tukang ojek. Selain itu dipaparkan beberapa respon masyarakat atas penutupan tersebut. Beberapa yang setuju menilai bahwa penutupan lokalisasi ini dapat membangun etos kerja yang lebih baik di lingkungan masyarakat sekitar lokalisasi, meminimalisir demoralisasi pada remaja dan anak-anak. Sementara yang kurang setuju menilai bahwa penutupan lokalisasi hanya menciptakan prostitusi liar dan bisa lebih buruk dari sebelumnya. Dengan ditutupnya Lokalisasi Dolly menggambarkan bahwa penutupan lokalisasi memberikan pengalaman yang sangat beragam di lingkungan masyarakat.
\end{abstract}

Kata Kunci: dampak sosial ekonomi; prostitusi liar; lokalisasi

\section{Abstract}

Dolly Localization closure by city officials to be one of the shocking news, because this localization is the localization of the largest in Southeast Asia. This study discuses the socioeconomic impact that caused of localization Dolly. The method used this study is the method to produce a qualitative descriptive writing. Source obtained through interviewers. Research findings show that the socio-economic impact caused by the closure of the localization is perceived by businessmen who derive their life in the area of localization. Business operators complained income levels started stated to decline, it is perceived by food and beverage stores, night guards, parking attendants, washerwoman to motorcycle taxi drives. Additionally described some of the public response over the closure. Some who agree considered that the closure of this localization can build a better work ethic within the community, minimizing the demoralization in adolescent and children. While less agrees considers that the closure of the localization of just creating illegal prostitution and could be worse than before. Socioeconomic impact caused by the closure of the localization Dolly that closing localization gives a very mixed experience within the community.

Keywords: socio-economic impact; illegal prostitution; localization

A.

\section{PENDAHULUAN}

Perkembangan kawasan perkotaan memiliki berbagai problematika yang lebih kompleks dibandingkan dengan kawasan pedesaan ataupun kawasan lain. Masalahmasalah sosial di perkotaan sangatlah luas, mulai dari kriminalitas, kemiskinan, kepadatan penduduk, pengangguran, pelacuran/prostitusi. (seperti di Kota Surabaya)

Masalah sosial memang banyak sekali, termasuk yang dapat dikategorikan sebagai penyakit masyarakat atau biasa disebut sebagai pathologi sosial, salah satunya adalah masalah pelacuran/prostitusi. Pelacuran merupakan 
masalah sosial tertua yang dikenal masyarakat, dan erat sekali kaitannya dengan masalah kemiskinan. Pelacuran dipandang sebagai gejala pathologis karena melanggar norma agama, sosial dan hukum serta merupakan salah satu bentuk penyakit masyarakat yang harus dihentikan penyebarannya.

Prostitusi merupakan salah satu bentuk penyakit masyarakat, yang harus dihentikan penyebarannya, tanpa mengabaikan usaha pencegahan dan perbaikannya. Pelacuran berasal dari bahasa latin pro-stiture atau prostauree, yang berarti membiarkan diri berbuat zina, melakukan persundalan, pencabulan, pergendakan. Sedangkan prostitue adalah pelacur atau sundal, dikenal pula dengan istilah WTS atau Wanita Tuna Susila.

Wanita Tuna Susila ini dianggap sebagai salah satu bentuk penyakit masyarakat, mereka juga dianggap sebagai kaum yang kurang beradab, dalam bentuk penyerahan diri pada banyak laki-laki untuk pemuasan seksual dengan mendapat imbalan uang dari pelanggannya yang telah dilayani.

Eksistensi Wanita Tuna Susila ini banyak menimbulkan penolakan dari berbagai pihak yang telah menganggap bahwa "profesi" Wanita Tuna Susila merupakan "profesi" rendahan, perebut suami orang, profesi dengan menjual harga dirinya dengan bisnis esek-esek, bahkan dari berbagai pihak tersebut, banyak yang menganggap bahwa Wanita Tuna Susila itu wanita "haram" yang tidak mendapatkan pendidikan agama dan pendidikan moral yang cukup.

Dolly, sebagai tempat prostitusi memang melegenda di Surabaya, bisnis esek-esek di kawasan ini disebut-sebut sebagai yang terbesar di Asia Tenggara. Di sana ada sekitar 1.187 PSK dengan jumlah mucikari 311 orang. Angka itu melonjak dibanding pada tahun 2012 sebesar 1.022 PSK dan 292 mucikari. Dalam semalam, perputaran uang di kawasan itu sekitar Rp. 2 miliar.

Semakin lama Gang Dolly semakin dikenal masyarakat. Kondisi tersebut kemudian berpengaruh pada kuantitas pengunjung dan sejumlah PSK serta Dolly juga menjelma menjadi kekuatan dan sandaran hidup bagi penduduk di sana. Ada lebih dari 800 wisma esek-esek, kafe dangdut, dan panti pijat plus. Setidaknya setiap malam sekitar 9.000 lebih penjaja cinta, pelacur di bawah umur, germo, dan ahli pijat siap menawarkan layanan kenikmatan kepada pengunjung. Bahkan seorang PSK dapat melayani 10 hingga 13 pelanggan dalam semalam. Bukan hanya itu, Dolly kemudian juga menjadi tumpuan hidup bagi ribuan pedagang kaki lima, tukang parkir, dan calo prostitusi. Semua saling terkait menjalin sebuah simbiosis mutualisme. Dolly kemudian mendapat predikat sebagai lokalisasi terbesar se-Asia Tenggara mengalahkan Patpong di Bangkok, Thailand dan Geylang di Singapura.

Di Dolly terkumpul ribuan PSK yang berasal dari sejumlah daerah seperti Semarang, Kudus, Pati, Purwodadi, Nganjuk, Sidoarjo, Sumenep, Malang, Trenggalek, dan Kediri. Sedangkan mereka yang berasal dari Surabaya bekerja di Dolly sebagai model paruh waktu atau freelance.

Menurut data Dinas Sosial, jumlah PSK Dolly-Jarak mengalami pembengkakan yang signifikan. Tercatat pada tahun 2014, PSK DollyJarak berjumlah 1.449. Jumlah ini bertambah 268 PSK dibanding tahun sebelumnya yang berjumlah 1.181. Seperti yang dikabarkan di berbagai media, tanggal 18 Juni 2014 Pemerintah Kota Surabaya telah memutuskan untuk melakukan penutupan salah satu Lokalisasi terbesar di Asia Tenggara tersebut. Penutupan Lokalisasi yang berada di Kelurahan Putat Jaya Dolly ini terbilang kontroversial karena dinilai akan berdampak pada masyarakat sekitar yang memperoleh manfaat dari Lokalisasi yang konon telah berdiri sejak jaman pasca penjajahan Belanda tersebut.

Tak bisa dipungkiri bahwa Lokalisasi Dolly menjadi salah satu magnet bagi datangnya para wisatawan ke Kota Surabaya. Dalam seharisemalam, uang yang berputar di Lokalisasi Dolly mencapai Rp. 350 juta hingga Rp. 500 juta. Uang berputar ini juga dinikmati oleh tukang parkir, taksi hingga masyarakat sekitar. Penghasilan yang didapat oleh tiap PSK mencapai Rp. 15 juta hingga 20 juta perbulan. Sementara sang Mucikari bisa mendapat Rp. 60 juta.

Penutupan Lokalisasi Dolly ini terbilang dilematis karena akan memberi dampak buruk bagi perekonomian dan kehidupan sosial masyarakat sekitar yang menggantungkan hidupnya dari keberadaan Lokalisasi Dolly yang menyerap tenaga kerja di berbagai sektor. Kehidupan sosial yang dirasakan masyarakat Dolly dan sekitarnya yang menggantungkan kehidupannya di lokalisasi tersebut sangat kaget karena dari Pihak Pemerintah Kota Surabaya sebelumnya kurang sosialisasi kepada masyarakat.

Sedangkan kehidupan ekonomi masyarakat Putat Jaya RW 11 yang menggantungkan kehidupannya di lokalisasi pasca penutupan dinataranya yaitu, masyarakat kehilangan pekerjaan sehari-hari yang selama ini mereka lakukan selama lokalisasi masih buka. Mulai dari pedagang makanan dan minuman 
yang menetap, tukang parkir, bisnis laundry pakaian, toko-toko kelontong, dan yang paling merasakan dampaknya adalah pengelola lokalisasi. Karena dirasa penghasilan mereka mengalami penurunan dan tidak cukup untuk memenuhi kebutuhan hidupnya, maka banyak di antara para pengelola lokalisasi mencari pekerjaan di luar area lokalisasi atau pindah profesi.

Dampak penutupan lokalisasi terhadap kehidupan ekonomi masyarakat sekitar Lokalisasi Dolly, berangsur-angsur secara signifikan mengalami perubahan oleh karena itu masyarakat perlu beradaptasi dengan kondisi tersebut. Rumusan masalah penelitian ini sebagai berikut:

1. Bagaimana dampak penutupan Lokalisasi Dolly Surabaya terhadap kehidupan ekonomi masyarakat sekitar Gang Dolly?

2. Bagaimana dampak perubahan sosial setelah penutupan Lokalisasi Dolly Surabaya?

\section{B. LANDASAN TEORITIS}

\subsection{Kebijakan Publik}

Kebijakan mengandung arti sebagai suatu rencana kegiatan atau pernyataan mengenai tujuan - tujuan yang diajukan atau diadopsi oleh suatu pemerintahan, partai-parti politik dan lainlain. Kebijakan juga diartikan sebagai pernyataan -pernyataan mengenai kontrak penjaminan atau pernyataan tertulis. Sedangkan Menurut Mustopadidjaja,(2002) Kebijakan Publik adalah suatukeputusan yang dimaksudkan untuk tujuan mengatasi permasalahan yang muncul dalam suatu kegiatan tertentu yang dilakukan oleh instansi pemerintah dalam rangka penyelenggaraan pemerintahan.

\subsection{Kebijakan PERDA Kota Surabaya Nomor 7 Tahun 1999}

Prostitusi adalah masalah sosial yang sulit untuk diatasi sampai sekarang ini. Berbagai macam alasan diajukan untuk menjawab kesulitan untuk memberantasnya. Kesulitan ekonomi dan tututan perut menjadi alasan utama para Pekerja Seks Komersial (PSK) dan orangorang yang mendapat keuntungan dalam "Industri Seks" ini untuk membela diri. Kesulitan untuk mendapatkan pekerjaan yang layak dan kerasnya persaingan bisnis yang terkadang antara halal dan haramnya tidak tampak batasan yang jelas juga menjadi alasan pendukung.

Peraturan Daerah Nomor 7 Tahun 1999 yang dikeluarkan oleh Pemerintah Kota Surabaya dan ditetapkan pada tanggal 11 Mei 1999 merupakan peraturan tentang larangan menggunakan bangunan atau tempat untuk perbuatan asusila serta pemikatan untuk melakukan perbuatan asusila di Surabaya.
Sesuai dengan Peraturan Daerah tersebut seperti yang tertera dalam Ketentuan umum pasal 1, yaitu:

a. Bangunan atau Tempat adalah bangunan permanen, semi permanen maupun tidak permanen serta tempat lain baik terbuka maupun tertutup.

b. Perbuatan Asusila, adalah perbuatan yang bertentangan dengan norma-norma kesusilaan, moral dan norma-norma agama, khususnya perbuatan seperti hubungan suami istri untuk memuaskan nafsu syahwatnya, tetapi tidak terikat dalam status pernikahan.

c. Pemikatan untuk melakukan perbuatan asusila, adalah segala perbuatan yang mengarah kepada perbuatan asusila yang dilakukan di tempat umum dengan maksud untuk menyuruh/mengajak atau menganjurkan orang lain untuk melakukan perbuatan asusila dengan yang bersangkutan, baik yang secara langsung maupun terselubung.

d. Pekerja Seks Komersial, adalah wanita yang melayani laki-laki yang bukan suaminya untuk memuaskan nafsu syahwatnya dengan memperoleh imbalan atau pembayaran.

e. Mucikari, adalah setiap orang yang mata pencahariannya baik sambilan atau sepenuhnya, menyediakan dan atau mengelola tempat untuk praktik Pekerja Seks Komersial.

f. Tempat Umum, adalah jalan, dan tempattempat lain yang dapat secara bebas dikunjungi setiap orang.

Dari pengertian tersebut di atas, Pemerintah Kota Surabaya melarang semua kegiatan maupun praktik asusila, baik yang dilakukan di jalan-jalan yang secara bebas dapat dikunjungi oleh semua orang maupun di tempat atau bangunan yang permanen, semi permanen maupun tidak permanen, terbuka atau terselubung.

\subsection{Evaluasi Kebijakan}

Sebuah kebijakan publik tidak bisa dilepas begitu saja, tanpa dilakukan evaluasi. Evaluasi kebijakan dilakukan untuk menilai sejauhmana keefektifan kebijakan publik untuk dipertanggung jawabkan kepada publiknya dalam rangka mencapai tujuan yang telah ditetapkan. Evaluasi dibutuhkan untuk melihat kesenjangan antara harapan dan kenyataan.

Menurut Winarno (2008:225) Bila kebijakan dipandang sebagai suatu pula kegiatan yang berurutan, maka evaluasi kebijakan merupakan tahap akhir dalam proses kebijakan. Namun demikian, ada beberapa ahli yang mengatakan sebaliknya bahwa evaluasi bukan merupakan tahap akhir dari proses kebijakan publik. Pada dasamya, kebijakan publik dijalankan dengan 
maksud tertentu, untuk meraih tujuan-tujuan tertentu yang berangkat dari masalah-masalah yang telah dirumuskan sabelumnya.

Dane (Wibawa, 1994) menyebutkan ada dua tipe evaluasi yaitu:

1. Sumative evaluation, adalah penilaian dampak dari suatu program, disebut juga dengan evaluasi dampak (out come evaluation)

2. Formative evaluation, adalah penilaian terhadap proses dari program, disebut pula evaluasi proses.

\section{METODE PENELITIAN}

Berdasarkan permasalahan yang diangkat, penelitian ini menggunakan pendekatan kualitatif. Penelitian dengan menggunakan pendekatan kualitatif merupakan prosedur penelitian dengan menghasilkan data deskriptif yang berupa kata-kata tertulis atau lisan dari orang-orang dan perilaku yang diamati. Pendekatan ini diarahkan pada latar dan individu tersebut secara utuh. Dengan menggunakan metode kualitatif peneliti mencari semua data yang dibutuhkan, kemudian dikelompokkelompokan menjadi lebih spesifik. (Bogdan dan Taylor, 1975 dalam Moleong, 2006).

\section{PEMBAHASAN}

\subsubsection{Dampak Kehidupan Ekonomi Masyarakat Sekitar Lokalisasi Pasca Penutupan}

Penutupan Lokalisasi Dolly memang sangat membawa dampak kepada masyarakat sekitarnya, khususnya masyarakat Kelurahan Putat Jaya yang menggantungkan hidupnya pada keberadaan lokalisasi. Perubahan yang terjadi bukan hanya masalah sosial akan tetapi sedikit banyak penutupan lokalisasi tersebut membawa dampak negatif pada sektor ekonomi masyarakat sekitar. Dampak perekonomian ini terlihat dengan tidak adanya PKL dan pedagang asongan yang ada di kawasan Lokalisasi Dolly seperti saat beroperasi.

\section{a. Berkurangnya jenis mata pencaharian}

Penutupan Lokalisasi Dolly menjadikan masyarakat Putat Jaya kehilangan mata pencahariannya dan mengharuskan mencari mata pencaharian yang baru, sebab dengan ditutupnya Dolly maka berkurangnya orang yang berkunjung di kawasan ini. Hal ini menjadikan masyarakat harus bekerja dan berusaha keras agar tetap dapat memenuhi kehidupannya sehari-hari

Akan tetapi sebagian masyarakat yang terdampak atas penutupan Dolly ini, sebagian dipekerjakan di dinas-dinas Pemerintah Kota
Surabaya, seperti halnya di Bankesbangpol Linmas, Dinas Perhubungan, Dinas Pendidikan dan lain sebagainya. Dengan diperkejakan ke dinas-dinas tersebut maka berkurangnya masyarakat yang belum mendapatkan pekerjaan baru. Seandainya tidak dipekerjakan seperti hal tersebut maka sekarang banyak yang bingung akan alih profesinya. Sebagaimana yang telah dikatakan oleh Suwarno :

"Saya disini sebagai Ketua Karang Taruna mas, mengaku senang sekali dengan kebijakan pemerintah yang menutup Lokalisasi Dolly, sehingga kami sebagai pemuda di Putat Jaya di jaring untuk menjadi Linmas Kota Surabaya. Tidak hanya saya mas banyak teman-teman dan juga orang-orang yang dulunya berdagang juga terjaring dalam perekrtutan tersebut. Bagi mereka yang dulunya tidak mau direkrut ya sekarang ini kebingungan mas akan pekerjaannya. Dolly wis tutup gak dapat pekerjaan." (Wawancara, Senin 26 September 2016 PK, 19.30)

\section{b. Berkurangnya Pendapatan}

Dengan ditutupnya Lokalisasi Dolly sangat jelas sekali mengakibatkan efek negatif bagi masyarakat dalam sektor ekonom, karena banyak pedagang yang sudah tidak lagi berjualan.

Mengingat adanya penutupan Lokalisasi Dolly yang mengakibatkan penurunan ekonomi di masyarakat Putat Jaya ini, PKL yang terletak di area Lokalisasi Dolly sepi dari pengunjung. Hal tersebut mengakibatkan terjadinya sedikit konflik dengan pihak yang mendapatkan pekerjaan di lingkungan pemerintah kota. Sebab dianggap tidak adil, hanya orang-orang tertentu saja yang dipekerjakan di lingkungan kota. Masyarakat yang belum mendapatkan pekerjaan tentunya sangat dirugikan.

\section{c. Peralihan fungsi lahan / wisma}

Perubahan fungsi lahan / wisma yang terjadi disini adalah perubahan fungsi wisma tersebut yang dulunya dijadikan sebagai tempat tuna susila sekarang menjadi tempat pembuatan sepatu dan ada juga yang dijadikan sebagai tempat usaha sablon bimbingan belajar dan masih banyak lainnya. Sebagaimana yang dikatakan Abah Ghufron (Tokoh Agama).

"Dulu wisma-wisma ini didalamnya banyak dihuni oleh PSK mas, ya di tempat situlah dijadikan tempat para hidung belang melampiaskan nafsunya. Yang setiap pagi, sore, 
siang bahkan malam hari tak pernah sepi dari pengunjung. Akan tetapi setelah adanya penutupan Lokalisasi Dolly pemerintah memiliki program alih profesi dan alih fungsi wisma. Sehingga sekarang ini sudah banyak wisma yang dijadikan sebagai tempat usaha swasta maupun pemerintah." (wawancara, 24 September 2016 Pk. 16.30 WIB)

Dari pengamatan peniliti ada sekitar 7 wisma yang sudah dibeli oleh Pemerintah Kota Surabaya dan telah diberi tanda bahwa tanah dan bangunan milik / asset Kota Surabaya. Wisma yang paling mahal adalah Wisma Barbara dengan tinggi 6 lantai, dengan dilengkapi lift. Wisma 6 lantai tersebut dibeli oleh Pemkot dengan harga 9 milyar dan wisma itu juga yang pertama dibeli oleh Pemkot Surabaya. Seperti yang disampaikan oleh Bapak Lurah Putat Jaya saat wawancara.

"Alhamdulillah kepedulian Pemerintah Kota Surabaya terhadap masyarakat Putat Jaya ini sungguh serius mas, buktinya pemerintah telah membeli bekas wisma di Dolly dan Jarak ada sekitar 7 wisma yang sudah resmi dibeli, tinggal 3 wisma lagi yang masih didekati oleh pemerintah untuk dibeli, do'akan agar cepat deal dengan pemiliknya. Semua wisma yang dibeli semuanya menjadi asset dan hak milik Pemerintah Kota Surabaya, yang dijadikan sebagai tempat usaha bagi masyarakat sekitar. Sekarang mas bisa lihat sendiri wisma Barbara tersebut sudah menjadi sentra UKM dan wisma-wisma lain yang sudah dibeli oleh Pemkot Surabaya, usaha-usaha tersebut adalah usaha digital printing, pembuatan sepatu, service sepeda motor, warnet, cuci mobil \& motor, telor asin, dan olahan kuliner lainnya sampai sekarang." (wawancara, 26 September 2016 Pk. 11.30 WIB)

Dari wawancara tersebut peneliti menemukan sebuah perubahan alih fungsi wisma menjadi tempat usaha mandiri bagi warga sekitar yang terdampak atas penutupan Lokalisasi Dolly Surabaya. Bekas wisma-wisma yang dibeli oleh Pemkot Surabaya tersebut dimanfaatkan oleh warga sekitar untuk bekerja mencari nafkah. Dan juga rencananya bekas wisma yang terbesar tersebut nantinya akan dijadikan sebagai pelayanan satu atap untuk RT dan RW bagi masyarakat sekitar.

Dari data di atas maka peneliti menemukan bahwa masyarakat yang dulunya menggantungkan kehidupannya di Dolly, saat ini beralih profesi bekerja di bekas wisma-wisma dulu yang mana usaha-usaha tersebut dikelola oleh pemerintah maupun pihak swasta.

\subsubsection{Dampak Perubahan sosial masyarakat sekitar lokalisasi pasca penutupan}

\section{a. Kesehatan}

Di tutupnya Dolly tersebut menjadikan semangat baru dalam bidang kesehatan, yang mana pada saat detik-detik penutupan Dolly banyak disosialisasi bahaya dari virus mematikan HIV/AIDS tersebut oleh Dinas Kesehatan Putat Jaya menjadikan efek takut bagi masyarakat terhadap virus tersebut. Sehingga mereka yang berpola pikir maju tentang kesehatan dapat mempengaruhi masyarakat sekitar untuk mempedulikan kesehatan pula.

\section{b. Kebersihan}

Pasca penutupan lokalisasi banyak selokan-selokan yang buntu. Ini disebabkan karena sudah tidak lagi ada yang membersihkan sepanjang jalan Dolly tersebut, sehingga membuat warga sekitar yang sangat dekat lokalisasi melakukan kerja bakti pada setiap minggu sehingga kebersihan kawasan ini sangat bersih dan masyarakat lebih kompak untuk membersihkan lingkungan

\section{c. Pola Pikir}

Setelah ditutupnya lokalisasi tersebut masyarakat sedikit berani ketika ada orang minum-minuman keras segera ditegur untuk disuruh pergi. Bahkan warga tak ragu-ragu untuk mengusirnya, ketika ada wanita-wanita berpakian seksi maka cepat-cepat menegurnya.

\section{d. Budaya}

Pasca penutupan Dolly mereka malu saat berpakaian seksi yang mengumbar aurat di jalanan, sehingga mengakibatkan budaya di masyarakat sekitar berubah menjadi lebih baik

\section{e. Sistem Kemasyarakatan}

Pasca penutupan Dolly kawasan ini menjadi sepi karena banyak ditinggalkan oleh penduduk musiman, sehingga berubah pula sistem kemasyarakatan yang ada di kawasan ini

\section{f. Keagamaan Masyarakat}

Setelah ditutup masyarakat sekitar sini banyak berdatangan ke masjid sekitar untuk melaksanakan sholat jama'ah. Hal yang sangat mempengaruhi kejadian tersebut karena tidak 
lagi ada suara keras musik-musik wisma, sehingga suara adzan dan pengajian yang ada di masjid sangat terdengar dengan jelas di sepanjang jalan Dolly ini

\section{g. Kegiatan Prostitusi:}

Pasca penutupan Lokalisasi Dolly ini berubahlah model prostitusinya, yaitu melalui alat elektronik e-Prostitusi. Yang mana makelar menyimpan foto PSK di Handphone, sehingga ketika ada pelanggan datang makelar tersebut menunjukkan foto wanita tersebut, ketika cocok maka eksekusi pelampiasan nafsunya di hotel kelas melati yang ada di Jl. Pasar Kembang Surabaya

\section{E. KESIMPULAN DAN REKOMENDASI}

\subsection{Kesimpulan}

Dengan adanya kebijakan dari

Pemerintah Kota Surabaya terkait penutupan Lokalisasi Dolly Surabaya maka dampak perekonomian yang dirasakan oleh warga sekitar lokalisasi menumbuh kembangkan perekonomian mandiri dan dijadikan tempat untuk meningkatkan perekonomian warga bagi mereka yang berminat dan bersungguh-sungguh untuk mencari nafkah.

Dampak sosial akibat penutupan Lokalisasi Dolly adalah masyarakat sekitar lokalisasi perlahan-lahan atau sedikit demi sedikit meninggalkan kebiasaan lama, hal ini disebabkan adanya perubahan kondisi, baik itu kondisi geografis, kebudayaan material, komposisi penduduk, ideologi dan juga adanya icon baru yakni kawasan bebas prostitusi yang bisa merubah kehidupan struktur-struktur yang ada di masyarakat Kelurahan Putat Jaya itu sendiri.

Jadi tanpa adanya usaha dari masyarakat itu sendiri untuk merubah nasib, merubah pola pikir hidup, merubah perilaku keagamaannya, merubah perilaku giat untuk bekerja tidak malas, maka kehidupan mereka akan tetap dan tidak akan berubah menjadi lebih baik.

Penutupan Dolly ini memberikan konstribusi bagi perubahan-perubahan yang ada di Kelurahan Putat Jaya, baik dalam hal sosial dan ekonomi. Masyarakat Putat Jaya menemukan hal-hal baru pasca ditutupnya Lokalisasi Dolly yaitu berupa kedamaian dan ketentraman, mereka sedikit demi sedikit meninggalkan kebiasaan lama untuk menuju kehidupan yang baru yaitu kawasan yang bebas prostitusi, sehat dan bersih.
Penutupan Dolly memberikan kebutuhan profesi alternatif bagi masyarakat terkait di dalamnya. Dengan adanya program-program pengentasan dan sentuhan modal usaha menjadi alternatif, beberapa PSK dan mucikari sudah bisa melakukan pekerjaan halal. Namun demikian, masih banyak kekhawatiran akan munculnya pelacuran terselubung yang meluas di tempattempat yang tidak bisa diawasi pemerintah.

Jadi temuan atau hasil penelitian tersebut sesuai dengan teori perubahan sosial dan ekonomi, bahwasannya perubahan itu terjadi harus melalui sebuah tindakan sosial, dimana masyarakat Putat Jaya harus berubah dan yang membuat perubahan adalah dari individu maupun kolektif.

Jika pola pikir masyarakat, pola hidup, keagamaan masyarakat mau berubah pasti pertumbuhan ekonomi dapat dirasakan, karena bagi peneliti penutupan lokalisasi ini sebagai proses kenaikan kapasitas produksi atau perekonomian masyarakat Kelurahan Putat Jaya menuju yang lebih baik.

\subsection{Saran}

Dari semua data dan hasil penelitian ditemukan beberapa kekurangan yang perlu diperbaiki, baik bagi warga maupun pihak pemerintah. Beberapa saran yang diajukan antara lain sebagai berikut:

a. Bagi masyarakat, untuk melakukan kebijakan politik ini tidak mudah, perlu adanya keberanian dan juga tekad yang kuat untuk menutup lokalisasi prostitusi Dolly tersebut, motif yang melatarbelakangi juga berdasarkan niat baik, untuk melindungi anak-anak kecil dari perbuatan yang tidak bermoral, membebaskan para PSK yang terpaksa bekerja seperti itu dengan alasan ekonomi dan lain-lain. Setidaknya memberi dukungan dan bekerjasama untuk mewujudkan Surabaya sebagai kota yang benar-benar green and clean, bukan hanya clean dari sampah makanan ataupun lainnya, tapi juga terhindar dari prostitusi.

b. Untuk pihak pemerintah, lebih peka lagi dengan realita, kebijakan ini tidak berhenti begitu saja hanya sampai pada usaha penutupan, tetapi juga menindaklanjuti kehidupan berikutnya bagi para pekerja yang turut tergusur oleh penutupan lokalisasi tersebut. Lebih memperhatikan pekerjaan warga sekitar yang menggantungkan rizkinya pada kehidupan ditempat lokalisasi sebelumnya. 
c. Untuk pihak keamanan yang dibawah naungan pemerintah, melakukan pengamanan yang lebih ketat lagi diberbgai daerah yang memungkinkan menjadi tempat pelarian para PSK yang telah tergusur dari Dolly. Juga mengaktifkan pengamanan di dunia maya, yang kini banyak ditemukan situssitus jual PSK online beredar yang mudah dijangkau dimana saja dan kapan saja.

d. Untuk pemerintah, menyediakan lapangan kerja sebagai ganti pekerjaan para mantan PSK yang menganggur tibatiba karena penutupan lokalisasi prostitusi tersebut. Memberikan pelatihan keterampilan, agar mereka bisa diterima kerja ditempat lain. Menyediakan solusi sebagai penawaran atas penutupan lokalisasi tersebut, diantaranya yaitu berusaha memenuhi kebutuhan fisik berupa makanan, pakaian dan tempat tinggal, serta memberikan informasi mengenai lapangan kerja. Memenuhi kebutuhan psikis juga berupa siramana rohani agar mereka termotivasi untuk tetap bertahan hidup dengan pekerjaan yang lain.

\section{F. REFERENSI}

AG, Subarsono, 2005. Analisa Kebijakan Publik. Yogyakarta : Pustaka Pelajar

A, Sunarto AS, Desember 2013, "Kyai dan Prostitusi : Pendekatan Dakwah KH. Muhammad Khoiron Suaeb di Lokalisasi Kota Surabaya." Jurnal Komunikasi Islam, Volume 03 , Nomor 02

Budi, Winarno, 1984. Kebijakan Publik: Teori dan Proses. Yogyakarta : Media Pressindo.

Cemi, Fitrianai, Jamal, 2010. Politik Prostitusi Kota Surabaya (Studi Deskriptif : Eksistensi Dolly). Skripsi Sarjana, Fakultas Ilmu Sosial Politik Universitas Airlangga, Surabaya.

Edi, Suharto, 2010. Analisa Kebijakan Publik Panduan Praktis Mengkaji Masalah dan Kebijakan Publik. Bandung: Alfabeta.

Fakih, Mansour, 1999. Analisi Gender dan Transformasi Sosial. Yogyakarta : Pustaka Pelajar.

George Ritzer, 1992. Sosiologi Ilmu Pengetahuan Berparadigma Ganda, Jakarta : Rajawali Pers

Gerungan WA, 2004. Psikologi Sosial. Bandung : PT. Refika Aditama.

Hakim, Abdul, 2014. Tri Rismaharini. Jakarta Selatan : Change.

Harrison, Lisa, 2007. Metodologi Penelitian Ilmu Politik. Jakarta : Kencana.

Hermawan, Diasmanto, 2011. “Dolly Ditutup, Prostitusi Menghilang?" Melalui http://www.republika.co.id/berita/jurnali sme-warga/wacana/11/06/09/Imik38dolly-ditutup-prostitusi-menghilang. $(21 / 04 / 2016)$

Hull, Terence $\mathrm{H}$ et al., 1997. Pelacuran di Indonesia, Sejarah dan Perkembangannya. 
Jakarta : Pustaka Sinar Harapan bekerjasama dengan The Ford Foundation

Jonaidi, Airus, 2012. Analisis Pertumbuhan Ekonomi dan Kemiskinan di Indonesia. : Jurnal Kajian Ekonomi.

Kardi, Dr. Ravik, 2004. Sosiologi Pendidikan. Surakarta : UNS Pers.

Kartono, Kartini, 2007. Patologi Sosial. Jakarta : PT. Raja Grafindo Persada.

Kuncoro, Mudrajad, 2006. Ekonomi Pembangunan. Yogyakarta : Percetakan STIM YKPN.

Mac Iver, 1937. Society a Textbook of Sosiogy.

Miftah, Toha, 2005. Dimensi-dimensi Prima Ilmu Administrasi Negara. Jakarta : PT. Raja Grafindo Persada.
Miskawi, 2013. Kelam Di Padang Bulan (Dinamika Kehidupan PSK Lokalisasi). Banyuwangi : PT. Alfastabiq Alkhairat.

Moleong, J Lexy, 2004. Metodologi Penelitian Kualitatif Edisi Revisi. Bandung : Remaja Rosdakarya.

Moch Andriansyah, 2014. "Gang Dolly Masih Kokoh, Tak Goyah Ancaman 'Singa Betina'" Melalui http://www.merdeka.com/peristiwa/gan g-dolly-masih-kokoh-tak-goyah-ancamansinga-betina. $(23 / 04 / 2016)$

Muhamad Nuradani, 2014. "Lokalisasi Dolly Ditutup" Melalui http://news.liputan6.com/read/2066763/1 okalisasi-dolly-ditutup. (23/04/2016)

Noor, Arifin, 1997. Ilmu Sosial Dasar. Bandung : CV. Pustaka Setia. 